\title{
Gut-hormone profile in totally pancreatectomised patients
}

\author{
H G DAMMANN, H S BESTERMAN, S R BLOOM, AND H W SCHREIBER
}

From the Medizinische Klinik und Abteilung für Allgemeinchirurgie der Universität Hamburg, Hamburg, and the Royal Postgraduate Medical School, Hammersmith Hospital, London

SUMMARY In eight totally pancreatectomised patients the release of the relevant gut hormones was determined after a standard test meal. Plasma levels of pancreatic glucagon were not significantly different from zero in our series of pancreatectomised patients. Pancreatic polypeptide was undetectable. These findings imply the absence of a significant number of normally functioning alpha cells and pancreatic polypeptide cells in extrapancreatic sites in man. Consistent with the antrectomy, duodenectomy, and resection of the upper jejunum that are performed in conjunction with a total pancreatectomy the gastrin release was significantly impaired. In contrast there was a striking postprandial rise in enteroglucagon probably induced by the rapid intestinal transit time often seen after partial gastrectomy. In contrast plasma motilin and GIP levels were normal. Pancreatectomised man thus presents an interesting model of total deficiency of endogenous insulin, pancreatic polypeptide, and pancreatic glucagon and, in addition, greatly diminished gastrin. The considerable derangement of metabolic and intestinal function that follows total pancreatectomy may, in part, be explained by this gross disturbance of the normal physiology of gut hormone.

The main indications for total pancreatectomy are carcinoma (ampullary, periampullary and pancreatic) and end-stage chronic pancreatitis. ${ }^{1-4}$ The major clinical problems that occur after total pancreatectomy arise from the pancreatic exocrine and endocrine insufficiencies that invariably follow the procedure. ${ }^{5}$ The resulting diabetes can be difficult to control in this clinical setting. The greatest clinical hazard in the management of apancreatic diabetes is insulin shock. Difficulty can be encountered in controlling the steatorrhoea despite an adequate replacement dose of pancreatic enzymes. A considerable number of patients fail to gain, and many even lose, weight after total pancreatectomy. ${ }^{16}$ Many factors may be relevant to this and it is difficult to single out whether it is the accompanying partial gastrectomy, the pancreatectomy, insufficient enzyme replacement, or the level of caloric intake which is responsible.

Both pancreatic exocrine and endocrine function are profoundly influenced by gut hormones and feedback mechanisms may exist. Thus the degree and clinical severity of the metabolic sequelae and the altered intestinal function that follow total pancreatectomy may well be influenced by abnor-

Received for publication 31 October 1980 malities in the release of gastrointestinal hormones. The partial gastrectomy, duodenectomy, and resection of the upper jejunum that are usually performed in conjunction with a total pancreatectomy may well result in at least partial removal of the source of some gut hormones. We have therefore compared the release of the relevant gut hormones in eight totally pancreatectomised patients, and in 11 ageand sex-matched normal control subjects.

\section{Methods}

\section{PATIENTS}

The stimulus for release of gut hormones was a standard test-breakfast consisting of two mediumsized boiled eggs, $60 \mathrm{~g}$ bread as toast, $10 \mathrm{~g}$ butter, $35 \mathrm{~g}$ marmalade, and $150 \mathrm{ml}$ unsweetened orange juice (containing a total of $18 \mathrm{~g}$ protein, $22 \mathrm{~g}$ fat, and $66 \mathrm{~g}$ carbohydrate equivalent to 530 Calories). Eight totally pancreatectomised patients (Table 1) were studied before their normal morning dose of insulin, without pancreatic enzyme supplement, and also 11 healthy controls (six males and five females), with a mean age of 43 (range 22-59) years and an average weight of $107 \%$ of ideal, none of whom had a present or past history of gastrointestinal disease. The efficacy of total pancreatectomy was confirmed 
Table 1 Clinical data on eight totally pancreatectomised patients

\begin{tabular}{llllll}
\hline $\begin{array}{l}\text { Patient } \\
\text { no. }\end{array}$ & $\begin{array}{l}\text { Sex } \\
\text { and } \\
\text { age } \\
(y r)\end{array}$ & $\begin{array}{l}\text { Weight } \\
(\mathrm{kg})\end{array}$ & $\begin{array}{l}\text { Height } \\
(\mathrm{cm})\end{array}$ & $\begin{array}{l}\text { Insulin } \\
\text { (units } \\
\text { day) }\end{array}$ & $\begin{array}{l}\text { Total pancreatectomy: } \\
\text { reason and date }\end{array}$ \\
\hline 1 & F54 & $45 \cdot 5$ & 164 & 20 & $\begin{array}{l}\text { Chronic pancreatitis } \\
1976\end{array}$ \\
2 & F65 & 50.9 & 163 & 20 & $\begin{array}{l}\text { Adenocarcinoma } \\
1965\end{array}$ \\
3 & M39 & $49 \cdot 3$ & 163 & 18 & $\begin{array}{l}\text { Chronic pancreatitis } \\
1977\end{array}$ \\
4 & M55 & $71 \cdot 1$ & 169 & 32 & $\begin{array}{l}\text { Chronic pancreatitis } \\
1967\end{array}$ \\
5 & F38 & $49 \cdot 2$ & 162 & 24 & $\begin{array}{l}\text { Chronic pancreatitis } \\
1976\end{array}$ \\
6 & M38 & $92 \cdot 0$ & 184 & 44 & $\begin{array}{l}\text { Chronic pancreatitis } \\
1977\end{array}$ \\
7 & M35 & 68.0 & 172 & 40 & $\begin{array}{l}\text { Chronic pancreatitis } \\
1976\end{array}$ \\
8 & M36 & $75 \cdot 0$ & 180 & 44 & $\begin{array}{l}\text { Adenocarcinoma } \\
1977\end{array}$ \\
\hline
\end{tabular}

Table 2 Hormone release and blood glucose in pancreatectomised patients

\begin{tabular}{|c|c|c|c|}
\hline & Controls & $\begin{array}{l}\text { Total } \\
\text { pancreatectomy }\end{array}$ & $\mathbf{P} \boldsymbol{T}$ \\
\hline \multicolumn{4}{|l|}{ Gastrin* } \\
\hline B & $5 \pm 0.5$ & $2 \pm 0 \cdot 2$ & $\mathbf{a}$ \\
\hline PR & $\overrightarrow{17} \pm 4$ & $3 \pm 0.6$ & $\mathbf{b}$ \\
\hline IIR & $1 \cdot 7 \pm 0.3$ & $0.2 \pm 0.1$ & $\mathbf{a}$ \\
\hline \multicolumn{4}{|l|}{ GIP* } \\
\hline B & $9 \pm 1$ & $16 \pm 3$ & e \\
\hline PR & $33 \pm 7$ & $46 \pm 12$ & NS \\
\hline IIR & $3.9 \pm 0.7$ & $5 \cdot 3 \pm 2 \cdot 1$ & NS \\
\hline \multicolumn{4}{|l|}{ HPP* } \\
\hline B & $15 \pm 3$ & - & \\
\hline PR & $116 \pm 19$ & 一 & \\
\hline IIR & $12 \cdot 9 \pm 2 \cdot 4$ & - & \\
\hline \multicolumn{4}{|l|}{ Pancreatic glucagon $\dagger$} \\
\hline B & $9 \pm 2$ & $5 \pm 0.6$ & NS \\
\hline PR & $3 \pm 2$ & $3 \pm 0.9$ & NS \\
\hline IIR & $0.3 \pm 0.3$ & $0.1 \pm 0.1$ & NS \\
\hline \multicolumn{4}{|l|}{ Motilin* } \\
\hline B & $63 \pm 8$ & $41 \pm 10$ & NS \\
\hline PR & $16 \pm 6$ & $48 \pm 6$ & b \\
\hline IIR & $-1 \cdot 1 \pm 0 \cdot 9$ & $4.9 \pm 0.9$ & $\mathbf{a}$ \\
\hline \multicolumn{4}{|l|}{ Enteroglucagon* } \\
\hline B & $32 \pm 7$ & $38 \pm 10$ & NS \\
\hline PR & $26 \pm 7$ & $89 \pm 23$ & d \\
\hline IIR & $2 \cdot 6 \pm 1 \cdot 0$ & $8.9 \pm 1.9$ & c \\
\hline \multicolumn{4}{|l|}{ Neurotensin* } \\
\hline B & $50 \pm 6$ & $49 \pm 7$ & NS \\
\hline PR & $22 \pm 3$ & $42 \pm 14$ & NS \\
\hline IIR & $1.8 \pm 0.4$ & $4 \cdot 3 \pm 2 \cdot 2$ & NS \\
\hline \multicolumn{4}{|l|}{ Blood glucose* } \\
\hline B & $4 \cdot 2 \pm 0 \cdot 2$ & $11 \cdot 6 \pm 2 \cdot 2$ & $\mathbf{b}$ \\
\hline PR & $1.6 \pm 0.3$ & $14 \cdot 7 \pm 1 \cdot 8$ & $\mathbf{a}$ \\
\hline IIR & $71 \pm 36$ & $2 \cdot 0 \pm 0 \cdot 3$ & $\mathbf{a}$ \\
\hline
\end{tabular}

All hormone levels (B: basal, PR: peak response) given as pmol/l $($ mean $\pm \mathbf{S E M})$; blood glucose levels given as mmol/1 (mean $\pm \mathrm{SEM})$.

*After test-breakfast-integrated incremental response (IIR) in $\mathrm{nmol} / \mathrm{l}$ (mean \pm SEM) over 180 minutes; blood glucose IIR in nmol!l (mean \pm SEM) over 180 minutes.

†P values vs. controls: a: $<0.001, \mathrm{~b}:<0.005$, c: $<0.01$, d: $<0.02$, e: $<0.05$. NS : not significant. by undetectable basal plasma levels of C-peptide. The operation of total pancreatectomy involved block resection of the pancreas, the duodenum, two-thirds of the distal stomach (Billroth IIresection), the upper part of the jejunum, the lower end of the common bile duct, the gall bladder, and the spleen, in conjunction with a gastro-jejunostomy.

In patient no. 1 large parts of the jejunum were bypassed by a distal enteroanastomosis. After this study, this patient suffered from massive steatorrhoea, despite adequate enzyme replacement, and intractable diarrhoea and died from an intercurrent infection.

Blood samples for subsequent hormone assays were taken into heparinised tubes and 400 kallikrein-inactivating units of aprotinin (Trasylol) per $\mathrm{ml}$ were added. Plasma was separated within 15 minutes of sampling and stored at $-20^{\circ} \mathrm{C}$ until assay.

Hormone radioimmunoassays were carried out by conventional methods with antisera raised to pure natural human gastrin ${ }^{7}$ and pancreatic polypeptide,${ }^{8}$ to porcine gastric inhibitory polypeptide $(\mathrm{GIP})^{9}$ total glucagon $\left(\mathrm{N}\right.$ terminal) ${ }^{10}$ pancreatic glucagon ( $\mathrm{C}$ terminal), ${ }^{11}$ motilin $^{12}$ and to bovine neurotensin. ${ }^{13}$

The assays could detect the following plasma changes with $95 \%$ confidence: gastrin $2 \mathrm{pmol} / \mathrm{l}$, pancreatic polypeptide $4 \mathrm{pmol} / \mathrm{l}$, GIP $8 \mathrm{pmol} / \mathrm{l}$, pancreatic glucagon $1.5 \mathrm{pmol} / \mathrm{l}$, enteroglucagon $8 \mathrm{pmol} / \mathrm{l}$, neurotensin $5 \mathrm{pmol} / \mathrm{l}$, and motilin 3 $\mathrm{pmol} / \mathrm{l}$. No cross-reaction was detectable between any of the peptides assayed.

\section{Results}

Basal (fasting) concentrations, maximum concentrations after the appropriate stimulus, total postprandial integrated release of each hormone, and blood glucose are given in Table 2.

\section{PANCREATIC GLUCAGON}

The pancreatectomised patients had a mean fasting pancreatic glucagon concentration of $1 \cdot 6 \pm 1 \cdot 5$ $\mathrm{pmol} / \mathrm{l}$, which was not significantly different from zero. The control group had a significantly greater mean fasting glucagon concentration of $7 \cdot 6 \pm 2 \cdot 3$ $\mathrm{pmol} / \mathrm{l}(\mathrm{P}<0.05)$. In neither group was there a significant change from basal levels in the post meal glucagon concentrations.

\section{GASTRIC INHIBITORY POLYPEPTIDE (Fig. 1)}

Normal subjects had a significant post-prandial rise in plasma GIP to $31.6 \pm 6.5 \mathrm{pmol} / 1$ at 60 minutes. Patients with total pancreatectomy had an equivalent peak of $45 \cdot 2 \pm 7 \cdot 0 \mathrm{pmol} / \mathrm{l}$. The total integrated 


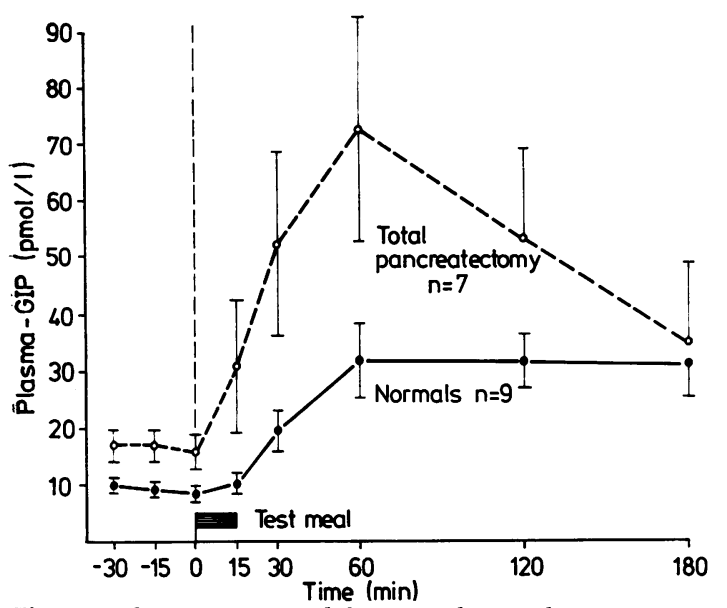

Fig. 1 Plasma gastric-inhibitory-polypeptide response to a test-meal in totally pancreatectomised patients.

release of GIP after the meal was not significantly different from that in the controls.

Patient no. 1 had plasma GIP concentrations considerably higher than the rest of the group, accounting for the large standard errors of the means.

ENTEROGLUCAGON (Fig. 2)

Basal plasma-enteroglucagon concentrations were similar in the two groups. After the meal there was a

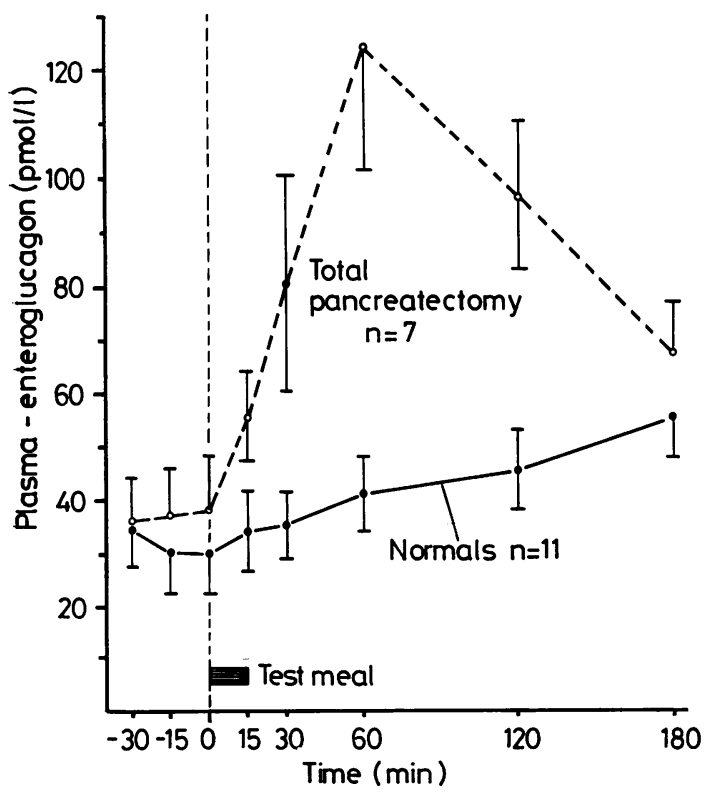

Fig. 2 Plasma-enteroglucagon response to a test-meal in totally pancreatectomised patients. much larger increase to $124 \cdot 1 \pm 22.9$ at 60 minutes in the pancreatectomised patients in contrast with $40.9 \pm 6.8 \mathrm{pmol} / \mathrm{l}(\mathrm{P}<0.005)$ in the normal subjects. The three hour total integrated release of enteroglucagon after the meal was also significantly increased in pancreatectomised patients $(15 \cdot 6 \pm 2 \cdot 1$ $\mathrm{nmol} / \mathrm{l})$ compared with controls $(8 \cdot 3 \pm 1 \cdot 1 \mathrm{nmol} / \mathrm{l}$. $\mathbf{P}<0.01$ ).

\section{NEUROTENSIN}

Though basal and post-breakfast neurotensin concentrations were not significantly different from normal controls the mean peak rise and total integrated decrease were higher in the pancreatectomised patients $(42 \cdot 0 \pm 14.0 \mathrm{pmol} / \mathrm{l}$ and $4 \cdot 3 \pm 2 \cdot 2 \mathrm{nmol} / 1$ than in the controls $(22 \pm 3 \mathrm{pmol} / \mathrm{l}$ and $1 \cdot 8 \pm 0 \cdot 4)$.

\section{PANCREATIC POLYPEPTIDE}

Pancreatic polypeptide was undetectable in the pancreatectomised patients, whereas the normal group had a maximal post-prandial rise in plasma pancreatic polypeptide of $116 \pm 19 \mathrm{pmol} / \mathrm{l}$.

\section{GASTR IN (Fig. 3)}

The pancreatectomised group of patients had significantly lower basal gastrin concentrations of $1 \cdot 8 \pm 0.2$ $\mathrm{pmol} / 1$ compared with controls $(5.0 \pm 0.5 \mathrm{pmol} / 1$, $\mathbf{P}<0.001)$ with a greatly reduced post-prandial rise of only $2 \cdot 1 \pm 0 \cdot 4 \mathrm{pmol} / 1$ (controls: $12 \cdot 3 \pm 3 \cdot 1 \mathrm{pmol} / \mathrm{l}$, $P<0.005)$.

\section{MOTILIN}

Plasma-motilin and total integrated release of this hormone after the test-breakfast were similar in the two groups.

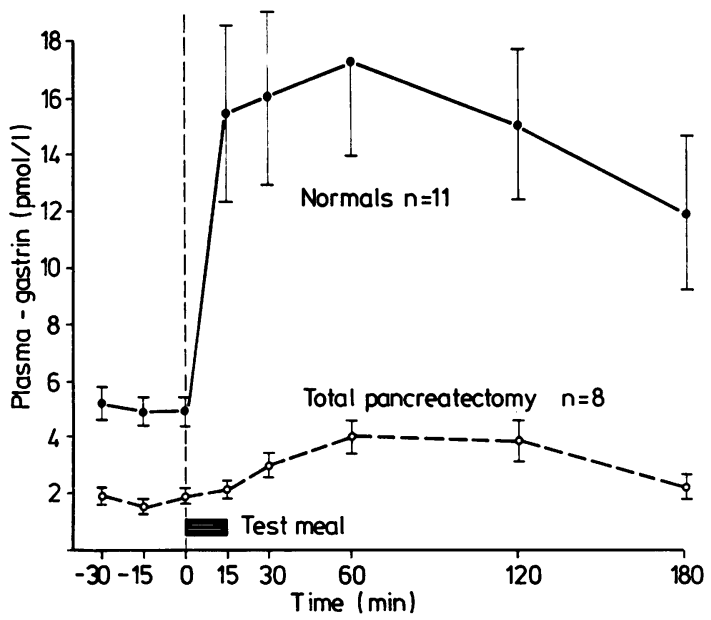

Fig. 3 Plasma-gastrin response to a test-meal in totally pancreatectomised patients. 


\section{Discussion}

Totally pancreatectomised man has been previously studied as a useful model for diabetes without glucagon. ${ }^{14}$ As in this earlier study with a different group of pancreatectomised patients, use of a highly sensitive and specific antibody showed plasma levels of pancreatic glucagon to be not significantly different from zero. The report of basal glucagon immunoreactivity in a totally pancreatectomised patient ${ }^{15}$ may reflect the lesser specificity of the antibody used. Pancreatic polypeptide was undetectable in our series of pancreatectomised patients. This is consistent with previous observations that pancreatic polypeptide is found in specific cells of both the endocrine and exocrine pancreas, ${ }^{16} 17$ and that pancreatic polypeptide cells are very rare in the intestine..$^{18}$ In man the plasma concentration of the hormone varies with the prandial state. ${ }^{819}$ Ingestion of a protein-rich meal induces a brisk, biphasic secretion pattern comparable with postprandial release of insulin. ${ }^{819-21}$

The physiological actions of pancreatic polypeptide are not fully elucidated but experiments in dogs suggested that it affected the biliary tract, the exocrine pancreas and gastric secretion. ${ }^{22}{ }^{23}$ Recent experiments in man, using physiological doses of infused bovine pancreatic polypeptide, indicated that it inhibited bilirubin and trypsin, ${ }^{24}$ but not gastric acid or pepsin..$^{25}$ As both known target organs (pancreas and gall bladder) are resected in these patients, the effect of pancreatic polypeptide is difficult to interpret. However, until its physiology and pathophysiology are fully understood, the possible consequences of a total lack of pancreatic polypeptide cannot be determined.

The significantly impaired gastrin release after total pancreatectomy is consistent with antrectomy. In addition, the duodenectomy and resection of the upper jejunum diminish the main sources of extragastric gastrin. ${ }^{26}{ }^{27}$ The incidence of gastrointestinal bleeding and ulcer disease after total or partial pancreatectomy seems to be low in spite of potentially impaired ability to neutralise acid in the duodenum consequent on impaired bicarbonate secretion Pliam et $a .^{6}$ and Mangold et al. ${ }^{28}$ observed no gastrointestinal bleeding or perforated ulcer in a group of 24 totally pancreatectomised and 44 partially pancreatectomised subjects. We have observed 13 pancreatectomised subjects who also developed no ulcer disease (unpublished observations). Others have reported similar findings. ${ }^{3}$ Increased antral or extragastric gastrin release after stimulation is believed to play a role in the pathophysiology of duodenal and gastric ulcer disease. ${ }^{27}$ Thus, it is tempting to speculate that in many of the cases the low incidence of gastrointestinal bleeding may be at least partly secondary to the impaired post-prandial gastrin-release secondary to the extensive surgery undertaken during pancreatectomy.

There was a striking post-prandial rise in enteroglucagon in the pancreatectomised subjects. Increased release of enteroglucagon has also been reported in coeliac disease and in the dumping syndrome. ${ }^{29}{ }^{30}$ Enteroglucagon is found in highest concentrations in the ileum ${ }^{31}$ and it is thought to stimulate mucosal growth and to slow intestinal transit. ${ }^{30}{ }^{32}$ In coeliac disease it has been claimed that the increased mucosal turnover and the slower transit time may be secondary to the raised enteroglucagon concentrations. In our study, the raised enteroglucagon levels were probably stimulated by the rapid intestinal transit time often seen after partial gastrectomy. In patient no. 1 large parts of the jejunum (about $1.5 \mathrm{~m}$ ) were bypassed by a distal Roux-enteroanastomosis. This patient had basal enteroglucagon values of $327 \cdot 7 \pm 18 \cdot 8$ and a peak of $381 \mathrm{pmol} / \mathrm{l}$. In contrast, however, the release of neurotensin, another hormone produced in the distal part of the small intestine, was normal in the totally pancreatectomised patients.

The totally pancreatectomised patients had plasma motilin levels which were not significantly different from normal. This is in contrast with the raised motilin levels found in patients with both mild and severe pancreatic disease. ${ }^{33}$ The latter subjects, however, have intact stomachs and upper small intestine-those areas where motilin exerts its actions, increasing the rate of gastric emptying ${ }^{34}$ and initiating the induction of interdigestive myoelectric complexes. ${ }^{35}$ The pancreatectomised patients studied here had also undergone duodenectomy and proximal jejunectomy. These areas contain the highest concentration of motilin cells. ${ }^{12}$ The finding of normal plasma motilin concentrations in these patients may reflect a compensatory increase in the rate of secretion of the few remaining motilin cells.

Basal levels of plasma GIP and the post-prandial GIP response in the pancreatectomised patients were not significantly different from normal, despite one patient having high levels. The duodenum and jejunum are the areas with the highest concentrations of GIP cells ${ }^{31}$ and thus, after surgery, the pancreatectomised patients will have lost a significant portion of the GIP secreting cells. The normal plasma GIP levels in these patients presumably reflects increased secretion by GIP cells further down the small intestine. One mechanism which might stimulate this is the lack of endogenous insulin, as it has been proposed that insulin normally inhibits GIP release by means of a negative feedback mechanism. ${ }^{36}$ 
Pancreatectomised man thus presents an interesting model of a total deficiency of endogenous insulin, pancreatic polypeptide, and pancreatic glucagon. In addition, there is also a greatly diminished mass of gastrin cells and, to a lesser degree, GIP and motilin cells. The considerable metabolic and intestinal derangements that follow total pancreatectomy may well reflect this gross disturbance of normal gut hormone physiology. Proper treatment of such patients thus depends on the recognition of the comprehensive nature of these abnormalities.

\section{References}

${ }^{1}$ Braasch JC, Vito L, Nugent FW. Total pancreatectomy for end-stage chronic pancreatitis. Ann Surg 1978; 188: 317-22.

${ }^{2}$ Child ChG, Hinerman Kauffman GL. Pancreaticoduodenectomy. Surg Gynecol Obstet 1978; 147: 529-33.

${ }^{3}$ Frey ChF, Child ChG, Fry W. Pancreatectomy for chronic pancreatits. Ann Surg 1976; 184: 403-14.

${ }^{4}$ Gourevitch A, Whitfield AGW. Total pancreatectomy. Br J Surg 1952; 40: 104-7.

${ }^{5}$ McCullagh EP, Cook JR, Shirey EK. Diabetes following total pancreatectomy: clinical observations of ten cases. Diabetes 1958; 7: 298-307.

'Pliam, MB, ReMine WH. Further evaluation of total pancreatectomy. Arch Surg 1975; 110: 506-12.

${ }^{7}$ Russel RCG, Bloom SR, Fielding LP, Bryant MG. Current problems in the measurement of gastrin release. A reproducible measure of physiological gastrin release. Postgrad Med J 1976; 52: 645-50.

${ }^{8}$ Adrian TE, Bloom SR, Bryant MG, Polak JM, Barnes AJ. Distribution and release of human pancreatic polypeptide. Gut 1976; 17: $940-4$.

${ }^{9}$ Bloom SR, Turner RC, Ward AS. GIP release, insulin release and inhibition of gastric acid. Gastroenterology 1977; $72:$ A3/813.

${ }^{10}$ Thomson JPS, Bloom SR. Plasma enteroglucagon and plasma volume change after gastric surgery. Clin Sci mol Med 1976; 51 : 177-83.

"Bloom SR. Hormones of the gastro-intestinal tract. Br Med Bull 1974; 30: 62-7.

${ }^{12}$ Bloom SR, Mitznegg P, Bryant MG. Measurement of human plasma motilin. Scand J Gastroenterol 1976; 11: suppl. 39, 47-52.

${ }^{13}$ Blackburn AM, Bloom SR, Ebeid FH, Ralphs DN. Neurotensin and the dumping syndrome. Gut 1978; 19: A447.

14Barnes AJ, Bloom SR. Pancreatectomised man: a model for diabetes without glucagon. Lancet 1976; 1 : 219-21.

${ }^{15}$ Villanueva ML, Hedo JA, Marco J. Plasma glucagon immunoreactivity in a totally pancreatectomised patient. Diabetologia 1976; 12: 613-6.

${ }^{16}$ Heitz Ph, Polak JM, Bloom SR, Adrian TE, Pearse AGE. Cellular origin of human pancreatic polypeptide (HPP) in endocrine tumors of the pancreas. Virchows Arch B 1976; 21 : 259-65.

${ }^{17}$ Pelletier G, Leclerc R. Immunohistochemical localiza- tion of human pancreatic polypeptide (HPP) in the human endocrine pancreas. Gastroenterology 1977; 72: 569-71.

${ }^{18}$ Larsson L-I, Sundler F, Hakanson R. Pancreatic polypeptide - a postulated new hormone: identification of its cellular storage site by light and electron microscopic immunocyto-chemistry. Diabetologia 1976; 12: 211-26.

${ }^{19}$ Schwartz TW, Stadil F, Chance RE, Rehfeld JF, Larsson L-I, Moon N. Pancreatic-polypeptide response to food in duodenal ulcer patients before and after vagotomy. Lancet 1976; 1 : 1102-5.

${ }^{20}$ Hayashi M, Floyd JC, Pek S, Fajans SS. Insulin, proinsulin, glucagon, and gastrin in pancreatic tumors and in plasma of patients with organic hyperinsulinism. J Clin Endocrinol Metab 1977; 44: 681-94.

${ }^{21}$ Rehfeld RCG, Stadil F. The effect of gastrin on basaland glucose-stimulated insulin secretion in man. J Clin Invest 1973; 52: 1415-26.

${ }^{22}$ Lin TM, Chance RE. Gastrointestinal actions of a new bovine pancreatic peptide (BPP). In: Chey WY, Brooks FP eds, Endocrinology of the gut, New Jersey: Slack, 1974; 143-5.

${ }^{23}$ Lin TM, Chance RE. Bovine pancreatic polypeptide (BPP) and avian pancreatic polypeptide (APP). Gastroenterology 1974; 67: 737-42.

${ }^{24}$ Greenberg GR, McCloy RF, Adrian TE, Baron JH, Bloom SR. Inhibition of pancreas and gallbladder by pancreatic polypeptide. Lancet 1978; 2 : 1280-4.

${ }^{25}$ Greenberg GR, McCloy RF, Adrian TE, Baron JH, Bloo SR. Effect of bovine pancreatic polypeptide on gastric acid and pepsin output in man. Acta Hepatogastroenterol 1978; 25 : 384-7.

${ }^{26}$ Bloom SR. Gastrointestinal hormones. Intern Rev Physiol 1977; 12: 71-103.

${ }^{27}$ Hansky J, Korman MG. Immunoassay studies in peptic ulcer. Clin Gastroenterol 1973; 2: 275-91.

${ }^{28}$ Mangold G, Neher M, Oswald B, Wagner G. Ergebnisse der Resektionsbehandlung der chronischen Pankreatitis. Dtsch Med Wochenschr 1977; 102: 229-34.

${ }^{20}$ Besterman HS, Bloom SR, Sarson DL. et al. Gut hormone profile in coeliac disease. Lancet 1978; 1: 785-8.

${ }^{30}$ Bloom SR. An enteroglucagon tumor. Gut 1972; 13: 520-3.

${ }^{31}$ Bloom SR, Bryant MG, Polak JM. Distribution of gut hormones. Gut 1975; 16: 821.

32 Jacobs LR, Polak JM, Bloom SR, Dowling HR. Does enteroglucagon play a trophic role in intestinal adaption? Clin Sci Mol Med 1976; 50: 14p.

${ }^{38}$ Besterman HS, Adrian TE, Christofides ND. et al. Gut hormone profile in pancreatic disease. Gut 1978; 19: A447.

${ }^{34}$ Christofides ND, Modlin IM, Fitzpatrick FL, Bloom SR. Effect of motilin on the rate of gastric emptying and gut hormone release during breakfast. Gastroenterology 1979; 76: 903-7.

${ }^{36}$ Itoh Z. Motilin-a hormone to control interdigestive gut motility. J Jap Biochem Soc 1977; 49: 197-212.

${ }^{36}$ Brown JC, Dryburgh JR, Ross SA, Dupre J. Identification and actions of gastric inhibitory polypeptide. Recent Prog Horm Res 1975; 31 : 487-532. 